\title{
Blodet fanger
}

Forurensning kan spores i blodet. Tidligere var blyforgiftning et problem, ettersom bly var nødvendig i mange deler av industrien - i trykkeribransjen, innen malingsproduksjon og skipsbygging og til sjøs (mønjemaling). Nå har nye materialer, blyfri bensin og strengere lover gjort problemet mindre i Vesten. 1. mai 1936 ble Ragnar Nævestads yrkeshygieniske gjennomgang publisert. Her redegjør han blant annet for hvordan man kan påvise bly i blod (Tidsskr Nor Lægeforen 1936; 56: 453-73).

Ettertrykk i dagspressen forbudt.

Fra Universitetets hygieniske institutt, (Chef: Professor, dr. med. Carl Schiøtz), og fra Oslo helseråd, (chef: Stadsfysikus A. Diesen).

\section{Blypåvirkning hos arbeidere i forskjellige yrker.}

\author{
Av Ragnar Nævestad.
}

Hamel var den første som påviste, at der i blodet under spesielle forhold finnes røde blodlegemer som ved farvning med basiske farvestoffer viser sig å inneholde blå granula. Undersøkt mikroskopisk med olje-immersjon kan de variere i størrelse fra såvidt synlige til knappenålshodestore. Undertiden er kornene sparsomt til stede, men de kan også ligge tett i tett. Ofte er de samlet i erytrocytenes randparti. Deres oprinnelse er omstridt. De ble tidligere opfattet som et degenerasjonstegn (Grawitz). Nu er de fleste forskere (bl. a. Sabrazè, Schmidt, Naegeli) enige om at de er tegn på en patologisk regenerasjon. For denne antagelse taler også at basofili ofte følges av andre regenerasjonstegn, som polykromasi og Howell-Jolly legemer. Ved det siste forståes røde blodlegemer som inneholder kjernerester.

Når man hovedsakelig støtter sig til en undersøkelse av basofil punktering, blir det første spørsmål som må avgjøres: I hvilken grad kan man av basofil punktering slutte sig til blyforgiftning, resp. blypåvirkning ?

Basofilt punkterte erytrocyter optrer ikke sjelden hos sunde mennesker, men da i ringe antall. Schmidt fant hos 110 friske personer to med mere enn 100 basofilt punkterte pr. million erytrocyter. Trautmann fant 21 pct. friske mennesker med basofil punktering, men bare 2 pct. med mere enn 100 pr. million. Selv har jeg til kontroll undersøkt 54 menn, hovedsakelig verkstedsarbeidere som ikke kom $\mathrm{i}$ forbindelse med bly. Av disse hadde seks 100, en 300 og de øvrige ingen basofilt punkterte.

Basofili er funnet ved alle former for anemi, men det er ingen hyppig foreteelse. Som oftest finner man her basofil punktering ved meget lav hemoglobinprocent og sterke tegn på regenerasjon.

Basofil punktering sees undertiden hvor kvikksølv, vismut, anilin eller cement optas i organismen.

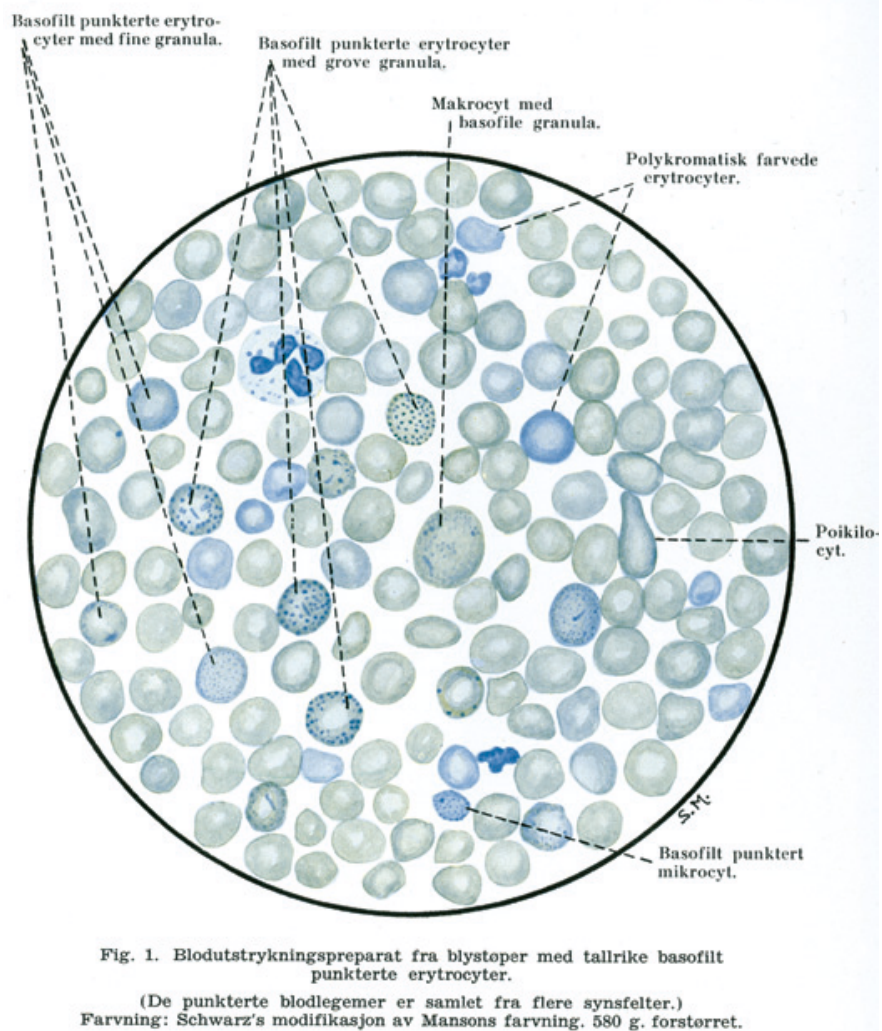

Den største rolle har imidlertid basofilien spilt for påvisningen av blyforgiftning eller blypåvirkning. Ved disse tilstander finner man meget hyppig basofilt punkterte blodlegemer og undertiden i stort antall, især hvor der samtidig er en moderat anemi til stede. Kornene er ofte meget store. 